\title{
A INVENÇÃO DO "SOCIAL"1 E A NORMATIVIDADE DAS CIÊNCIAS SOCIAIS: DILEMAS CLÁSSICOS E TENDÊNCIAS CONTEMPORÂNEAS
}

Este artigo analisa a pertinência teórico-prática fundante da sociologia na modernidade ${ }^{2}$ diante do dilema de empobrecimento em massa dos trabalhadores, que envolve uma dupla consequência epistemológica: o papel da sociologia na crítica social, ao contrapor-se ao utilitarismo de uma sociedade organizada em torno do "interesse"; ${ }^{3}$ e o seu papel racionalizador na estruturação das sociedades urbano-industriais pela busca do conhecimento objetivo.

O uso da noção de modernidade, neste artigo, refere-se a um tempo histórico de mudança social organizado com base no progresso técnico e em novas formas de regulação social inerentes à ordem urbano-industrial capitalista. A noção contém um valor moral contra a tradição, pelo imperativo da razão (Touraine, 1992). Observando a transição dos diversos sistemas de proteção social na Europa no século XIX, autores como Alexis de Tocqueville (1958) e George Simmel (1988) analisaram a passagem dos regimes de proteção privados, próprios à caridade cristã e à filantropia, para a institucionalização de um sistema de proteção em termos da responsabilidade pública do Estado moderno, e suas implicações sobre a condição da cidadania e a posição dos beneficiários da assistência na estrutura social.

O uso da noção de "invenção social", inspirada no título homônimo do livro de Jacques Donzelot (1994), busca apreender o conjunto de intervenções públicas (direito e políticas sociais) na passagem de regimes de proteção privados (próprias ao Antigo Regime) 4 para a construção dos sistemas de proteção social implementados pelo Estado, e assentados no direito, em diversos países da Europa no século XIX. Neste artigo, mais que a descrição dos sistemas de proteção sociais, a expressão tem caráter heurístico, teórico e metodológico: ela se refere tanto à natureza de um processo histórico, no qual se processaram formas específicas de encaminhamento da assistência aos mais pobres, mas também um processo de conhecimento e desvelamento crítico da ordem social, que discute as possibilidades da política. De acordo com princípios da ideologia liberal, na sociedade industrial capitalista o indivíduo poderia transcender as suas próprias condições materiais (de pobreza) e responsabilizar-se pela sua 
própria vida por meio do "trabalho" e do uso da "razão"s: é o sentido da "emancipação do indivíduo" da perspectiva liberal, cuja crítica mais contundente foi formulada por Karl Marx \& Friedrich Engels, no século XIX. Esse dilema implicou desafios epistemológicos à sociologia, na modernidade, considerando a dimensão cultural e histórica que institui a prevalência desta ciência na organização da sociedade.

O artigo problematiza a emergência da questão social clássica como questão pública, entendendo "a produção em massa de trabalhadores empobrecidos" como um problema de interesse geral, cujo encaminhamento resultou de embates e lutas, sustentados em concepções e normas de justiça e de equidade social, entre forças sociais e políticas distintas (liberais e socialistas) à época. Esse debate traz implícitas demandas normativas da cidadania, com base nos valores da equidade e do bem-estar material, mas envolve, também, princípios de racionalização, pela institucionalização da assistência e do seguro social aos membros da comunidade política, pelo Estado.

Essas concepções e princípios determinaram formas históricas singulares de intervenção do Estado na área social, mais amplas ou mais restritas, na regulação do conflito de interesses entre as classes, com base na gestão e organização da economia, pela redistribuição. Neste sentido, a análise desloca-se de regimes políticos específicos de países europeus, para assumir a natureza de um paradigma mais geral do estado de bem-estar, entre democracia e socialismo, que orienta as formas encontradas para diversos países ${ }^{6}$ no encaminhamento da questão social em regimes de proteção particulares. A concepção de um "Estado-providência" (Rosanvallon, 1981) passou gradativamente a se referir a diversos sistemas de proteção social criados no contexto da sociedade industrial da Europa, que buscavam efetivar diferentes graus de justiça e legitimidade, especialmente mediante a capacidade de redistribuição da renda. Seria a organização política da "desmercantilização" do trabalho pelo acesso ao seguro e a um conjunto de benefícios, na forma de prestações sociais (Esping-Andersen, 1990).

A dimensão pública da questão social implicou gradativamente o aprisionamento da razão iluminista de bem-estar pela razão instrumental, que encobre processos de dominação, como analisa Habermas (1987). Para recolocar o potencial emancipatório da razão iluminista ele adota o ponto de vista da ação comunicativa pela qual os conflitos intersubjetivos, a ação política e os princípios racionais revitalizam as decisões na esfera pública e orientam os conteúdos normativos do mundo da vida. ${ }^{7}$ Habermas faz uma crítica contundente à crescente instrumentalização do sistema na modernidade, por restringir a dimensão normativa exclusivamente à instância técnica, mas acabou reconhecendo o papel do direito como mediador relevante entre o mundo da vida e o sistema. Essa crítica é formulada por Arendt (1983) neste artigo, ao refletir sobre a formulação da questão social. Por outro lado, essa mesma crítica fundamenta o nosso debate sobre a passagem de uma perspectiva mais universalista dos direitos sociais 
para a adoção de um modelo residual e estratégico orientado para a alocação dos benefícios sobre os mais necessitados, que, no contexto contemporâneo vem assumindo prevalência nas reformas do Estado social em diversos países.

O desdobramento dessas questões obedece ao seguinte percurso: em primeiro lugar, o artigo situa conceitualmente os significados da expressão "invenção do social", caracterizando-a como uma noção híbrida entre a sociedade civil e a sociedade política, que encaminha a passagem da proteção social para o âmbito de uma responsabilidade pública. Apresenta a grande invenção da propriedade social de usufruto privado, caracterizado pelo sistema de seguro e conclui acentuando duas perspectivas distintas de segurança social: uma ligada ao direito à vida e à reprodução social; e, a segunda, associada à segurança civil, que acentua um caminho repressivo da ordem social. Na segunda parte, o artigo discute o fundamento moral normativo da sociedade liberal orientado pelo "interesse", contrapondo a crítica social do homo sociologicus ao homo œconomicus. Mostra como as ciências sociais estão diretamente implicadas na modernidade pelo seu papel racionalizador, quando associado à funcionalidade das instituições modernas, o que traz consequências teóricas e políticas. A terceira parte apresenta os principais diagnósticos clássicos sobre o fenômeno da pobreza, como uma categoria relevante do homo sociologicus, mostrando o caráter controverso, político e não essencialista da abordagem da questão social como questão pública. A análise mostra a passagem dos dispositivos normativos da modernidade para a regulação das políticas sociais.

Na sequência, o artigo sistematiza algumas ambivalências da noção de "social" como um campo de regulação não mercantil, mas também referido aos sujeitos e trabalhadores empobrecidos, concluindo com a formulação crítica da tecnificação da política, levantada por Arendt. Na conclusão, o artigo introduz algumas inflexões da reforma do Estado social nos anos 1990 e 2000, que envolve ruptura da relação entre proteção, trabalho e solidariedade nacional e apresenta, de forma introdutória, alguns paradigmas contemporâneos que enfrentam o dilema da flexibilização das relações de trabalho e a garantia do direito universal à proteção pela adoção de uma política de renda mínima da cidadania.

\section{A QUESTÃo SOCIAL COMO A INVENÇÃO SOCIAL}

Consideramos "invenção social" a criação de condições sociais, políticas e institucionais implícitas às instituições do Estado moderno, como os direitos e políticas sociais, que acompanharam as regulações do mercado de trabalho na formação das sociedades urbano-industriais na Europa. Assumimos esta perspectiva a partir da obra clássica de Karl Polanyi A grande transformação (2000), que reconstitui um conjunto de regulamentações protetoras voltadas para compensar as contradições de um mercado de trabalho livre, o qual, apesar 
dos benefícios gerados, não conseguia superar a destruição e degradação social implícitas à sua constituição, na sociedade inglesa:

[...] o mercado de trabalho foi o último dos mercados a ser organizado sob o novo sistema industrial, e esse passo final só foi tomado quando a economia de mercado foi posta em marcha e a ausência de um mercado de trabalho provou ser um mal ainda maior para o próprio povo comum do que as calamidades que acompanhariam a sua introdução. No final, o mercado livre de trabalho, a despeito dos métodos desumanos empregados em sua criação, provou ser financeiramente benéfico para todas as partes envolvidas.

Entretanto, agora surgira o problema crucial. As vantagens econômicas de um mercado livre de trabalho não poderiam compensar a destruição social que ele acarretaria. Tiveram que ser introduzidas regulamentações de um novo tipo para mais uma vez proteger o trabalho, só que agora, contra o funcionamento do próprio mecanismo de mercado. Embora as novas instituições protetoras - sindicatos e leis fabris - fossem adaptadas, tanto quanto possível, às exigências do mecanismo econômico, elas interferiam com sua auto-regulação e finalmente destruíram o sistema (Polanyi, 2000: 99).

O entendimento dessas mudanças em termos de "invenção social" não significa uma nominação de Karl Polanyi a estes processos, mas destaca a capacidade heurística desta expressão para dar conta da construção histórica de um conjunto de intervenções públicas (direito e políticas sociais) que envolveram a passagem de regimes de proteção privado para a construção dos sistemas de proteção social implementados pelo Estado.

Essa expressão foi usada por Jacques Donzelot (1984) para analisar o processo de constituição do Estado e sua mediação na efetivação dos direitos civis e sociais na ordem republicana francesa, com vistas a compatibilizar o interesse individual com o interesse coletivo e para proteger os trabalhadores quanto aos riscos imprevistos no âmbito da nova organização do trabalho capitalista.

O primeiro aspecto da questão social consiste [...] numa dramática revelação da ambivalência inerente ao conceito fundador da República, o da soberania - a ponto de tornar impossível qualquer determinação clara da esfera legítima de intervenção do Estado: atribuindo ao mesmo tempo a todos e a cada um a fonte de toda autoridade, a soberania faz, por consequência, oscilar o papel do Estado entre o tudo ou o nada. [...] A questão é, então, encontrar um princípio estável de governo, próprio a conter essa oscilação e a definir claramente as atribuições do Estado e seus limites, para que a República perdure (Donzelot, 1994: 73; as referências dos títulos em francês foram traduzidas pela autora).

A Revolução Francesa, ao romper com um sistema político de privilégios e protagonizar a instauração de uma sociedade de indivíduos, assume, desde o século XVIII, com a Declaração dos Direitos do Homem e do Cidadão, a tarefa de encaminhamento de uma política social, que foi tornando a caridade e a assistência clerical cada vez mais aleatória. À esta época, “o frágil equilíbrio necessário para tornar a solidariedade eficaz, entre a riqueza e a pobreza, entre a generosidade e o sofrimento, se torna a cada dia mais difícil e ilusório. 
Aumenta a miséria, e a caridade organizada de forma privada nada pode fazer, já que é insuficiente e mal distribuída", analisa Gonçalves (2009: 17) a partir de textos históricos da época. ${ }^{8}$

A esses processos institucionais, que se propagaram por toda a Europa, agregamos analiticamente os dilemas fundantes da grande ambição sociológica na formulação de um conhecimento crítico e normativo dessa ordem social burguesa, à época organizada em torno do "interesse" e que teve em Marx o seu maior crítico. Nesse sentido, os fenômenos da pobreza em massa dos trabalhadores e as desigualdades sociais, que emergem no contexto da sociedade da abundância, constituem-se nas manifestações empíricas sobre as quais se explicita grande parte da crítica social na modernidade, confrontados ao mito do progresso e ao valor moral implícito à "norma do bem-estar material" das sociedades capitalistas. Questão social e questões sociológicas se entrelaçam em movimentos reflexivos.

Diante da incompatibilidade dos interesses diversos a sociedade respondeu com a noção da solidariedade. Essa noção influenciou a linguagem intelectual de juristas, sociólogos e historiadores, fazendo autonomizar a dimensão social, numa ordem social e pública que oscilava entre duas forças sociais: a do liberalismo e a do marxismo. Nesse sentido, a "invenção do social", teorizada por Durkheim pela noção de solidariedade dos laços sociais, ${ }^{9}$ traduzia esses mecanismos sociais e institucionais que permitiam relativa coesão social à ordem social burguesa, de caráter instável, dadas as contradições e conflitos subjacentes às classes na ordem socioeconômica e política capitalista.

É no campo contraditório entre as utopias solidaristas e socialistas e as formas concretas desagregadoras do progresso material inerente à reprodução da ordem socioeconômica das sociedades capitalistas, particularmente a degradação e empobrecimento das classes trabalhadoras, confrontada ao princípio liberal de emancipação dos sujeitos, que a questão social emerge como questão pública, e o seu encaminhamento na forma institucional do seguro expressa uma "inovação social", voltada para mediar as contradições entre as classes e gerar pontos de interseção das instâncias econômica, política e da ordem familiar, no contexto das sociedades industriais modernas do século XIX.

Esta solução representou uma resposta da sociedade do século XIX (na Europa) à crítica marxista sobre o caráter formal da igualdade e da liberdade política, do ponto de vista da democracia liberal. Diante das desigualdades socioeconômicas e da degradação das condições de trabalho, os socialistas indagavam, entre outras questões: em que medida o indivíduo que não come e não dispõe de meios para ganhar a vida é um sujeito verdadeiramente livre (Schnapper, 1991)?

Polanyi analisava que a fome, vivenciada pelo conjunto dos trabalhadores na emergência das manufaturas, é um fator propício à sujeição e dependência dos trabalhadores aos proprietários: 
[...] a fome não é apenas uma pressão pacífica, silenciosa e incessante, mas, como a motivação mais natural para a diligência e o trabalho, ela se constitui no mais poderoso dos incentivos. Quando satisfeita pela livre generosidade de outrem, ela cria os fundamentos mais seguros e duradouros para a boa vontade e a gratidão. O escravo deve ser compelido a trabalhar, mas o homem livre deve ter seu próprio julgamento e critério; deve ser protegido no pleno gozo do que tem [...] (Polanyi, 2000: 140).

Robert Owen, um dos pensadores ingleses que analisara detidamente a sociedade industrial, diante das condições de degradação e pauperização dos trabalhadores, tanto os da cidade como os das aldeias, avaliou: "eles estão agora numa situação infinitamente mais degradante e miserável do que antes da introdução dessas manufaturas, de cujo sucesso depende agora sua mera subsistência" (apud Polanyi, 2000: 156). Ele enfatiza mais a degradação e a miséria que os rendimentos e aponta como causa dessa degradação as formas de dependência desses indivíduos à fábrica para a mera subsistência. Assim, mais que um problema econômico, Polanyi destaca na fome um problema social, devido à condição de exploração do trabalho, reconhecendo, entretanto, que, "a despeito das condições de exploração, eles [os trabalhadores] estavam financeiramente melhor que antes" (Polanyi, 2000: 157).

As condições de exercício da democracia, diante da crescente pauperização dos trabalhadores, ao final do século XIX, em toda a Europa, deram lugar, portanto, a uma "invenção social" assentada não mais sobre uma solidariedade de vínculos primários, mas na ideia de uma solidariedade nacional, que só poderia ser vivida num regime de liberdade, e que, àquela época, se projetou na construção do Estado-providência, na França. Aron (1969) considerou que os direitos sociais e o direito-liberdade não se contrapõem, mas são complementares, sendo os direitos sociais uma condição para o exercício da liberdade, ou seja, uma condição para a liberdade política.

No pós-Guerra, essa concepção de proteção social evoluiu para a formação do estado de bem-estar social, assentada na ideia do seguro obrigatório em diversos países do mundo sob a base do contrato, cujo modelo implica a cotização prévia dos trabalhadores para o seu usufruto futuro, quando perdem parcial ou definitivamente a capacidade de trabalho.

\section{A INVENÇÃO DA PROPRIEDADE SOCIAL DO ESTADO: A PROPRIEDADE DA “TRANSFERÊNCIA" E DA REDISTRIBUIÇÃO}

Na vigência da ordem liberal, como garantir a todos os cidadãos o direito a um bem-estar social mínimo? Esta seção apresenta a solução clássica da questão social encaminhada por diversos países da Europa, com base na "invenção da seguridade", que singulariza a construção de um patrimônio social com usufruto privado. 
Efetivamente, na nova ordem industrial de "homens livres", mas sem propriedade, os indivíduos têm necessidades pessoais que precisam satisfazer por meios pessoais, por exemplo, continuar a se alimentar, a morar, mas eles não dispõem de patrimônio privado. Esse dilema vai orientar a criação das instituições modernas, o estabelecimento das novas mediações sociais e institucionais na reprodução da sociedade, com a formação do Estado social, na forma de dispositivos institucionais de direitos e políticas de caráter social, como analisa Castel (1995). Esta concepção distingue-se da percepção dos liberais que consideram a propriedade privada o único fundamento da ordem social.

O dilema era o seguinte: pode existir um patrimônio de usufruto pessoal, mas que não seja privado? Ou, dito de forma inversa: um patrimônio que tenha um caráter social, mas seja de uso privado? A resposta a essa questão foi encontrada em Hammond (apud Castel, 1995: 310) por meio das prestações do seguro obrigatório: um patrimônio cuja origem e regras de funcionamento são sociais, mas que são, de fato, funções de um "patrimônio privado". Esta dimensão social da propriedade operada pelo Estado nunca foi aceita pelos liberais, pois envolveria para eles um risco à propriedade privada, e limitaria a acumulação, pois a instituição da propriedade social do Estado social intervém sobre o mercado, ainda que a concepção do seguro contributivo esteja apoiada sobre um princípio contratualista, condicionado pela cotização prévia para usufruto futuro.

Diante do papel mediador do Estado na sustentação do seguro social, Castel (1995) analisa a "propriedade de transferência" do Estado social. O pagamento das cotizações constitui uma obrigação inevitável, mas abre um direito inalienável. A propriedade do "assegurado" não é um bem vendável, mas é limitada por um sistema de constrangimentos jurídicos e as prestações são liberadas pelas agências públicas. É uma propriedade para a segurança ou garantia, e distingue-se da "providência" ou "benevolência" de uns em relação a outros. O Estado nacional assume a institucionalidade dessa forma de proteção social e de guardião de uma nova ordem de redistribuição de bens sociais. Castel reconhece na propriedade de segurança mediada pelo Estado um ponto de partida de uma teoria da regulação sob a forma de uma socialização das rendas, que vai se constituir cada vez mais numa parte importante das rendas socialmente disponíveis.

O encaminhamento da questão social, pressionada pelas lutas políticas dos trabalhadores, representa assim uma dimensão estruturante da ordem social capitalista, e significa, ao mesmo tempo, uma "política possível" diante das contradições das forças sociais, no sentido de minimizar as condições de exploração da força de trabalho e garantir aos trabalhadores, no campo dos direitos sociais, suas condições de reprodução contra os riscos advindos dos períodos de inatividade por idade ou doença. Esta solução contribuiu em parte para reduzir as desigualdades socioeconômicas (entre proletários e proprietários) pela redistribuição de riquezas e acesso dos trabalhadores e suas famílias aos direitos sociais básicos na defesa da vida. 
Considerando o papel estruturante e mediador da seguridade diante das contradições entre o econômico e o político na ordem social burguesa, pode-se associar a "invenção" da seguridade social como um "fato social total", no sentido atribuído por Marcel Mauss. Este compreendeu a vida social essencialmente como um sistema de prestações e contraprestações que obriga a todos os membros da comunidade, da perspectiva de um paradigma da solidariedade. Diferentemente da dimensão contratualista do seguro assentada na contrapartida das prestações econômicas, a crítica antiutilitarista inspirada na tradição de Mauss, quando aplicada à responsabilidade pública das prestações do Estado, questiona toda tentativa de limitar as motivações humanas apenas à moral do interesse ou à hegemonia da economia de mercado, na produção do bem-estar social. Essa perspectiva de Mauss constrói as bases para se repensar alternativas contemporâneas da relação entre proteção, trabalho e solidariedade social, a exemplo do debate atual sobre a instituição da renda básica universal com base no paradigma da dádiva, como apresentamos ao final.

\section{A NOÇÃO OBJETIVA DA PROTEÇÃO SOCIAL: RESPONSABILIDADES COLETIVAS E DIREITOS SOCIAIS}

O encaminhamento da questão "social", através da seguridade, corresponde, para Donzelot (1994) a uma "invenção" híbrida, construída na interseção do civil e do político (liberdades políticas e igualdade social), associada à preocupação de neutralizar as contradições existentes no âmbito da sociedade civil e mercantil, produzidas nas sociedades capitalistas industriais e que se opõem ou questionam o imaginário político ou a utopia da modernidade e o seu horizonte iluminista do "progresso".

Essa "inovação social" implica, portanto, uma transição histórica que envolveu tanto avanços na construção de um sistema teórico e autorreflexivo sobre a sociedade (a sociologia), como princípios normativos e de ação assentados numa moral de solidariedade, orientada segundo o princípio de igualdade para todos, e que se legitimou pela necessidade de minimizar o conflito social para além do sonho republicano de uma sociedade voluntarista e criação de instituições modernas.

No âmbito institucional, passou-se de um regime baseado na responsabilidade individual e fundado no direito civil para um regime de solidariedade assentado num contrato social e fundado na noção de direito social (Ewald, 1986), mediante um conjunto de leis relacionadas às condições do trabalho e à proteção aos trabalhadores que perderam a capacidade do uso da força de trabalho (doenças, invalidez, desemprego, velhice, acidentes etc.).

Assim, a noção de responsabilidade social, antes restrita ao âmbito da moral caritativa individual, passa a uma noção coletiva da proteção social. Ou seja, o direito social criou as condições de intervenção do Estado na prevenção de 
perigos que ameaçam a sociedade, e consolidou o princípio de uma responsabilidade pública institucionalizada ${ }^{10}$ no Estado social. Este mecanismo assenta-se na instauração de uma propriedade social (mas de uso pessoal) para o conjunto dos cidadãos e se distingue da noção de propriedade privada liberal. Mas o direito que protege os trabalhadores das condições de vulnerabilidade e risco é, ao mesmo tempo, um direito de todos, e mesmo restrito à uma matriz corporativa influencia o conjunto da sociedade na expansão dos direitos sociais, ampliando gradativamente o papel do Estado pelas transferências via políticas públicas.

A instituição do direito social (com base no "cálculo do seguro" e no contrato social) acompanha, portanto, essa "invenção" e busca proteger os indivíduos contra os prejuízos e riscos advindos da nova divisão social do trabalho no regime capitalista. Essa formulação de direitos à proteção avançou de uma ideia generalizada de direitos civis para outra, do nosso Direito, nosso direito social, que define compensações para os trabalhadores e suas famílias, diante dos prejuízos e riscos a que estavam submetidos, em face da divisão social do trabalho, como explicita Donzelot (1994: 11). Esses direitos sociais contrapõem-se ao direito de propriedade e subvertem de alguma forma o princípio de subordinação implícito aos contratos de trabalho. Eles socializam de alguma forma a economia e reforçam a integração social das famílias trabalhadoras, num contexto em que a propriedade privada os separa. Buscam assegurar o ideal do "pertencimento igualitário", no âmbito da ordem política, na garantia desses direitos, apesar das reconhecidas e profundas desigualdades na matriz socioeconômica. Assim, ao longo da história do capitalismo, a inserção nas relações assalariadas contém uma contradição: ela é uma condição de sujeição do trabalhador, mas se constitui ao mesmo tempo no espaço onde os trabalhadores exercem seus direitos de negociação e formalizam as suas condições de proteção social, cujo resultado ao longo da história tem se expressado numa regulação pública da reprodução social, mediante direitos dos trabalhadores.

A noção de responsabilidade também se modifica, passando de um princípio caritativo da moral religiosa, que se apoiava na providência e na filantropia da Igreja para uma responsabilidade coletiva, a partir da obrigação socializada dos processos aleatórios de riscos da vida, chamando a sociedade a implicar-se coletivamente.

Assim, a noção de "proteção" social, atrelada tradicionalmente às formas de sociabilidade primárias (família, comuna, religião), passa a ser encaminhada gradativamente como questão social pública, e de direitos, como preocupação social e função do Estado e um dos mecanismos de sua legitimação social. Perrot (1992) mostra que, desde o século XVII, filósofos economistas, como Vauban e Fénelon, propuseram uma revisão da fiscalidade, de forma a permitir aos mais pobres viverem decentemente e participarem da riqueza do reino. Vovelle (1978) analisa que, apesar de as administrações reais não estarem preparadas para empreender as reformas radicais devido a uma avaliação dos li- 
berais de que os pobres não deveriam ser objeto da responsabilidade do Estado, os autores do Iluminismo preconizavam uma intervenção do Estado na área social.

A Revolução Francesa proclamou o direito à segurança, e deu lugar a inúmeras polêmicas e a políticas de Estado diferentes: de um lado, a que acentua o princípio da segurança dos bens ou das pessoas e, de outro, aquela orientada para a garantia da liberdade e do direito à vida, expressando-se como direito ao trabalho ou à renda da assistência (Lévy, 2003: 8). A abordagem que privilegia a segurança civil foi encaminhada pelo aparato de repressão, enquanto aquela relativa ao direito à vida, ao trabalho e à assistência, efetiva-se pelos direitos sociais, numa concepção de reconhecimento de relativa igualdade entre os cidadãos. A tensão entre essas duas concepções de proteção - a da segurança pública ou a da segurança social - se inscreve na história das lutas sociais e políticas no curso dos últimos séculos, como proteção civil e proteção social. "Assim, nas sociedades contemporâneas, a seguridade é do domínio público e se aplica ao interesse comum. A segurança da população é também a garantia da sua liberdade. Ela é ao mesmo tempo individual e coletiva" (Lévy, 2003: 8).

\section{REFLEXIVIDADE E INTERESSE: ${ }^{11}$ O HOMO GCONOMICUS E O HOMO SOCIOLOGICUS NA MODERNIDADE}

O conjunto das mudanças históricas da modernidade foi acompanhado por um esforço autorreflexivo e crítico sobre esta própria ordem social, que se constituiu na "ambição sociológica", voltada para desnaturalizar a ordem social subordinada à hegemonia do mercado. As ciências sociais, assim, estão diretamente implicadas na modernidade, pelo papel racionalizador da sociologia na compreensão dos fenômenos sociais, implicitamente associado à estruturação das instituições modernas.

Como analisam os estudiosos da modernidade (Touraine, 1992; Giddens, 1994; e Martucceli, 1999, entre outros), a "consciência" da modernidade só se constitui verdadeiramente nesse duplo movimento, como consciência de pertença a um tempo específico (à sociedade urbano-industrial) e por uma vontade de dar sentido e de intervir no mundo, construindo a utopia de uma sociedade harmônica e coesa, na versão solidarista, que orientou a constituição da sociologia da integração durkheimiana, no final do século XIX; ou de um projeto de emancipação das classes sociais e da dominação do Estado capitalista, na versão revolucionária marxiana.

Trata-se de um modelo de reflexividade no qual não existe paralelismo entre a acumulação do conhecimento sociológico, de um lado, e o controle progressivamente do desenvolvimento social, do outro. [...]. O impacto das ciências sociais e das teorias sociológicas é, no entanto, enorme; as descobertas e os conceitos 
sociológicos, como os dados empíricos, são elementos constitutivos do que é a modernidade (Giddens, 1994: 24-25).

Há, portanto, uma "dupla hermenêutica", como formula Giddens, que diz respeito à forma como o conhecimento proveniente das ciências sociais é apropriado pelos atores sociais, em suas práticas, disposições e representações, e, por sua vez, como tais modificações induzem a novas análises, modificando a realidade anterior. Analiticamente, "Existe um vaivém entre o universo da vida social e o saber sociológico, e neste processo o saber sociológico se modela e remodela o universo social" (Giddens, 1994: 24).

A modernidade compreende, portanto, da perspectiva aqui analisada, profundas transformações da sociedade urbano-industrial capitalista europeia, organizada em torno do trabalho e da constituição do Estado-nação e, ao mesmo tempo, uma abertura à compreensão da ordem social e do progresso social a partir do uso da ciência e da racionalidade, ${ }^{12}$ entendida como um sistema racional e ordenado pela relação entre causa e efeito regido pela razão que assumiu, no positivismo, uma forma de empiria.

Se as ciências sociais possuíam uma pertinência prático-ideológica na modernidade, foi, portanto, por uma "razão normativa" particular, que continha uma consequência epistemológica: a busca de um "conhecimento objetivo". Assumindo a ideologia da legitimação e as finalidades próprias à modernidade, as ciências sociais pretenderam se identificar com um modelo de cientificidade "positivo", próprio às ciências da natureza, que apreendia a sociedade de maneira instrumental (Freitag, 1987: 63). O positivismo das ciências sociais, ao explicar a atividade humana com base no método experimental integrava, portanto, esse projeto de sociedade "racional", no qual a razão se identificava com a ideia de "liberação" da pessoa humana soberana e livre, no capitalismo. Augusto Comte atribuiu à ciência essa nova missão de presidir a ordem social, da mesma forma como as ideias religiosas haviam presidido a ordem social no passado. Ou seja, a modernidade pertence ao mundo dos homens pela ação reflexiva ${ }^{13}$ do conhecimento da sociedade e pelas possibilidades que esta consciência e essas técnicas têm de intervir sobre essa realidade, superando os antigos constrangimentos da religião e da tradição, que estruturavam a ordem social do Antigo Regime.

A sociologia contém, assim, uma "razão teórica" da crítica social (implícita no projeto sociológico), no esforço de desnaturalizar as contradições e dilemas da nova ordem social, que valoriza a inovação e o progresso, e uma "razão prática" e instrumental, como nos fala Habermas, apoiada na busca da objetividade e da sistematização do conhecimento, de forma a intervir sobre a sociedade a partir de exigências estritamente definidas pela ordem humana, pelos interesses materiais e individuais das classes sociais na produção da riqueza, utopia produtiva e base de estruturação da ordem sobre a qual os homens formulavam as leis e calculavam benefícios, tentando controlar a destruição social inerente 
à própria ordem do capitalismo. Como analisa Michel Freitag (1987: 17) "a busca da objetividade positiva no conhecimento da sociedade, no século XIX, impôs-se, também, e paradoxalmente, como palavra de ordem normativa". ${ }^{14}$

Como "razão prática", a sociologia profissionaliza-se na produção de informações sobre a vida social, suscetíveis de permitir o controle das instituições sociais. Esse princípio de intervenção racional sobre a vida social foi acompanhado de técnicas de contagem e recenseamentos sobre as condições de vida social, que além de subsidiarem o processo do conhecimento, se impõem também como necessidade política, já que os agregados que compõem uma "população" não são neutros, mas objeto de poder e riqueza, e operam a via funcional da "razão prática" instrumental. No entanto, se essa contradição sociológica entre a crítica e a regulação social expressa os dilemas clássicos das ciências humanas e sociais, não se pode desconhecer que o desenvolvimento das instituições sociais modernas e a profissionalização da sociologia em todo o mundo colaboraram para melhores condições de segurança e bem-estar, que aquelas vivenciadas nas sociedades tradicionais.

\section{O “INTERESSE" COMO PRINCÍPIO ESTRUTURANTE DA CULTURA MODERNA}

Assim, as dimensões do progresso técnico e da razão, na modernidade, naturalizaram-se, como norma de sociabilidade, situando sua historicidade sobre dois limites: o da "crise da tradição", da ordem social que a antecedeu, e o da construção de uma sociedade organizada com base no princípio do interesse, nem sempre conciliável, entre a acumulação e a reprodução dos trabalhadores, entre o interesse individual e o coletivo, estruturando a organização econômica e política da sociedade moderna.

Desde o século XVII, o "interesse" transformou-se no ordenador natural da sociabilidade humana na cultura burguesa, instituindo-se para além do próprio jogo do mercado e das trocas. Ele funda uma representação do mundo de natureza utilitarista, ${ }^{15}$ pela qual os vínculos humanos não mais se estruturam sobre uma moral e crença religiosa comum, como na tradição, mas pela constituição dos múltiplos interesses individuais contraditórios e sob a hegemonia da vida econômica. Este princípio influencia todas as relações sociais e instituições sociais e políticas, que passam a ser consideradas também como parte da esfera econômica, e objeto de cálculo. Ou seja, essa subordinação e funcionalidade do social e da sociedade ao princípio da utilidade passa a se constituir no princípio estruturante da cultura e da política das sociedades burguesas ocidentais, tanto no plano das representações sociais como das estruturas.

Assim, o paradigma utilitarista não constitui apenas uma doutrina, mas contém, ao mesmo tempo, uma dimensão plenamente "social", já que ele se insere nas práticas dos sujeitos e na estruturação das instituições sociais da vida moderna urbano-industrial. Nesse sentido, o utilitarismo não é apenas 
uma ideologia, mas diz respeito, também, às estruturas fundamentais das sociedades industriais ocidentais, articulando esse princípio e essa ideologia às práticas sociais dos agentes, os localizando, hierarquizando e estratificando, como homens úteis ou inúteis a essa ordem burguesa.

A doutrina propõe uma imagem do homem indissociável das condições materiais concretas. É o "ser egoísta", essencialmente econômico - o homo œconomicus -, sempre identificado com o cálculo racional, analisado por Weber. Esse axioma do homem calculista racional pensa a reorganização social e a refundação da ordem social e política, as instituições e políticas sociais da ordem moderna como uma ordem "natural". A razão que o caracteriza é contabilizável, supõe apenas a adequação dos meios aos fins.

Elisa Reis, num artigo de 1989, contrapõe o homo œconomicus (weberiano) ao homo sociologicus do paradigma solidarista (durkheimiano). Ela mostra como o primeiro é referencial para as mais diversas disciplinas:

Todas elas teriam indivíduos maximizantes, variando apenas a natureza do objetivo maximizado. Ou seja, o homem arquetípico seria o mesmo: o indivíduo possessivo e egoísta que, no afã de realizar suas paixões, age de forma utilitária. Mesmo quando a ação aparece disciplinada e regulamentada por cláusulas contratuais, o contrato aparece apenas como instrumento da vontade calculista e soberana do indivíduo (Reis, 1989: 25).

É incontestável a dimensão econômica na representação utilitarista do interesse, mas esse paradigma não se restringe apenas aos fenômenos econômicos e se expande, também, sobre as dimensões sociais e políticas de caráter coletivo: no limite, o calculador da utilidade geral é o legislador e o próprio Estado. Produzir coletividades é a chave do novo vínculo social. "Contra a lógica férrea do comportamento individual maximizante, ela [a sociologia] afirma a existência de um referente coletivo que é inseparável do próprio indivíduo. A idéia básica é a existência de algo além das puras motivações individuais, algo que conforma e dá sentido a essas motivações" (Reis, 1989: 25).

Essa articulação indissociável entre a dimensão individual e "social”, entre a sua efetivação e suas representações constitui-se o constructo típico do homo sociologicus, sendo a sociologia científica o lugar específico dessa inteligência, mas, também, o polo de resistência da produção dominante. Portanto, se a "utilidade" é o princípio do bem-estar "individual", ela não é inseparável de uma cultura de organização científica da sociedade moderna, nem das formas institucionais que organizam a vida coletiva.

A hegemonia do econômico sobre o social foi objeto de análise por diferentes autores da sociologia clássica, considerando distintas abordagens, dimensões e mediações. Todo esforço analítico da obra de Marx e Engels estruturou uma crítica radical voltada para a desmitificação da ordem capitalista tida como ordem natural orientada para a ideia de bem-estar individual e crescimento econômico das nações. 
Por meio de uma teoria da história Marx desvenda a natureza do capital como relação social. O fetichismo da mercadoria instituída na falsa ideia das trocas equivalentes expressa a dominação implícita na tendência à redução do valor da força de trabalho e da subsunção do trabalho ao proprietário. Pela articulação do materialismo dialético (a Filosofia do conhecimento do marxismo) e uma teoria da histórica (o materialismo histórico) ele faz contundente crítica às liberdades formais da democracia liberal, à emancipação do sujeito da perspectiva liberal, mobilizando as próprias noções econômicas do mercado de trabalho, para mostrar como nelas estão implícitas as formas modernas de exploração e subsunção daqueles trabalhadores "livres" ao capital, tanto no âmbito das relações econômicas, como da construção ideológica da "troca entre iguais". A superação dessa condição, para ele, portanto, implicava a constituição do trabalhador em sujeito coletivo, que, à época, ultrapassaria seus interesses particulares, em defesa de toda a sociedade.

Durkheim analisa a transição teorizando sobre a natureza do novo vínculo social próprio às sociedades modernas, mediante a noção de solidariedade social, como forma de mediação necessária à coesão das sociedades modernas. A análise do Contrato social em Rousseau mostra que o confronto dos interesses múltiplos, num regime de liberdades, tem efeitos contraproducentes implícitos a esses próprios interesses, e sua resolução implica um "contrato social". Max Weber entende que a ação social só pode ser compreendida pelo sentido que os agentes sociais lhe atribuem e, por essa via, a ciência pretende explicar causalmente seus desdobramentos e efeitos. Alexis de Tocqueville produz uma crítica ao capitalismo, mas, como liberal, é menos pessimista sobre a nova ordem estruturada pelo interesse. Ele considera que a relação de utilidade e a representação individualista contêm também capacidade de laços sociais e de prescrição moral, apesar de reconhecer os riscos do individualismo pelos efeitos indesejáveis da "atomização" da sociedade ou pelas possibilidades do "despotismo burocrático". A partir de observações da América, ele considera que o princípio do interesse econômico nem sempre levaria à desintegração social se a sociedade for suficientemente "ativa" e "associativa", submetida às instâncias coletivas, nas quais o interesse individual se relativiza diante do interesse do "outro", do coletivo etc.

Ou seja, a análise sociológica e política, sob diferentes perspectivas, tende a desenvolver a crítica do paradigma utilitarista, economicista, tomando por base muitas destas próprias premissas econômicas. No entanto, todas as relações induzidas pelo interesse, produtos espontâneos de necessidades e desejos individuais, são, elas próprias, problemáticas e conflituosas: como conciliá-las? Como garantir a unidade necessária à ordem social? O campo das polêmicas sociais refere-se à capacidade de inventar alternativas capazes de garantir a unidade da sociedade, a natureza dos vínculos humanos e das relações sociais, o que implica a mediação simbólica e ideológica, capaz de alimentar a utopia da 
"coesão social" pela via da reforma social. O deslindamento deste "simbolismo social" e da ideologia implícita à representação do utilitarismo está, portanto, no centro da ambição sociológica. ${ }^{16}$ Contra a ideia da vida estruturada no mercado, a sociologia propõe uma refundação cultural e social, implícita na renovação da crença de valores da solidariedade e/ou da luta política capazes de enquadrar as energias liberadas das sociedades industriais e mercantis.

Polanyi descreve como a consciência da sociedade teve por base a economia política:

Do pesadelo da população e das leis salariais destilou-se a esperança [...] e ela se materializou num conceito de progresso tão inspirador que parecia justificar as enormes e dolorosas distorções por vir [...]. A pobreza representava a sobrevivência da natureza humana. A limitação de alimentos e a ilimitação dos homens chegaram a um impasse justamente quando surgia a promessa de um aumento ilimitado da riqueza [...]. Foi assim que a descoberta da sociedade integrou-se no universo espiritual do homem. Mas de que forma essa nova realidade da sociedade seria traduzida em termos de vivência? (Polanyi, 2000: 10, grifos meus).

A dimensão da pobreza, nesse trecho de Polanyi - menos que um destino de indivíduos "moralmente condenados" nessa nova ordem, limitado "pela procriação da sua raça ou a condenar-se irremediavelmente à liquidação através da guerra e da peste, da fome e do vício" - tinha um significado de resistência, nas formas da sobrevivência desses indivíduos trabalhadores e suas famílias submetidos às condições de extrema pobreza.

\section{A POBREZA COMO CATEGORIA DO HOMO SOCIOLOGICUS}

A emergência das desigualdades econômico-sociais, no contexto do progresso e da acumulação da riqueza, constitui, então, uma das manifestações empíricas sobre a qual se formulou a crítica social na modernidade. O seu enfrentamento continha um duplo movimento epistemológico: (1) a construção de representações sociais adequadas à norma do bem-estar social material dos trabalhadores; e (2) a consciência de uma distância imediata entre essa norma de bem-estar e progresso e a realidade, pela qual a "emancipação" do indivíduo não se converteu em progresso material para todos. É esse paradoxo explicitado nas distâncias entre a riqueza e a pobreza, mediadas pelas relações de subordinação do trabalho na ordem capitalista que se constituíram, em parte, nos "desafios da modernidade, autodeterminada e autolegitimada em referência à negação da tradição" (Freitag, 1987: 19). Assim, a emergência de trabalhadores pobres e miseráveis no âmbito das sociedades da abundância e do progresso, o aumento das desigualdades sociais entre os homens diante do ideário liberal se transformam em questão social (e pública) e, igualmente, estão na base do projeto sociológico. 
O dilema era saber como garantir a liberdade e a igualdade próprias aos ideais democráticos, frente às condições humanas degradadas do homem livre e ao pauperismo dos trabalhadores? Como restaurar os vínculos sociais, quando a cidadania política abstrata constitui tanto o princípio da legitimidade política como a fonte do vínculo social, no sentido abstrato do termo?

Karl Polanyi (2000: 108) afirma que "foi em relação ao problema da pobreza que as pessoas começaram a explorar o significado da vida numa sociedade complexa". E, do ponto de vista prático, acrescenta que o encaminhamento dessa questão social assumiu duas perspectivas opostas: por meio do princípio da harmonia e da autorregulação, de um lado, e o da competição e conflito, do outro. Para ele, "o liberalismo econômico e o conceito de classes foram moldados dentro dessas contradições”. Mediante uma cuidadosa recuperação histórica da sociedade inglesa, esse autor mostra como os pobres emergiram na Inglaterra da primeira metade do século XVI, desligados da sociedade feudal, e que sua transformação gradual em classe trabalhadora livre resultou da perseguição à vagabundagem e do patrocínio da indústria doméstica. Nesse processo, enquanto os pobres, no século XVI, representavam um "perigo" para a sociedade, no final do século XVII, para os liberais, eles passaram a representar uma carga de maiores impostos para a sociedade, fundamentando as teses críticas quanto ao modelo de seguridade, que acompanham as tensões do welfare sobre a crise fiscal e o aumento dos gastos sociais, desde os anos 1970 do século XX.

\section{O pauperismo, a pobreza e os pobres na sociologia clássica}

Essas observações foram analisadas e teorizadas por vários autores do século XIX a respeito do fenômeno do pauperismo. As contribuições de Alexis de Tocqueville, Karl Marx \& Friedrich Engels, e Georg Simmel expressam interpretações críticas distintas relativas à reprodução da pobreza no contexto das sociedades urbano-industriais europeias, particularmente da Inglaterra e da França. O ponto de partida de todos estes se refere à transição da ordem feudal ao capitalismo, na qual, não obstante a ideia de progresso e a produção da riqueza, também se produzem e reproduzem, no capitalismo, a pobreza massiva expressando enormes desigualdades sociais. Para Marx, no entanto, a pobreza não diz respeito aos atributos morais de sujeitos incapazes, como consideravam os liberais da época, mas resulta diretamente das condições de estruturação do mercado de trabalho capitalista, condicionado pela reprodução da acumulação. No Capítulo XXIII de o Capital, ele analisa: "Assim como os trabalhadores tornam os homens ricos, quanto mais trabalhadores houver, mais haverá homens ricos..., o trabalho dos pobres é a mina dos ricos" (Marx, 1975: 762). Através da noção de "superpopulação relativa", Marx destaca a função de uma população trabalhadora "excedente" sobre as condições de reprodução do capital, bem como as possibilidades de sua organização em classe: 
Mas se uma superpopulação trabalhadora é o produto necessário da acumulação ou do desenvolvimento da riqueza sobre uma classe capitalista, esta superpopulação, por sua vez, se converte em alavanca da acumulação capitalista e inclusive em condição de existência do modo capitalista de produção [...] (Marx, 1975: 786-787).

Para Tocqueville (1958), a questão se refere à responsabilidade pública sobre os desvalidos e a vigência de direitos da cidadania nas sociedades democráticas liberais. Ele tece uma critica aos direitos dos pobres à assistência pública, considerando que estes podem produzir uma desqualificação social da cidadania. Para ele, a caridade deve ser atribuída aos setores privados e não uma responsabilidade coletiva pública.

Paugam (2005: 20) considera que tanto em Tocqueville como em Marx a pobreza correspondia mais a uma questão social que a um objeto específico da sociologia. Se ambos tentaram colocar esta questão na evolução das sociedades e a construir um quadro analítico que permitisse interpretar o funcionamento social, eles não definiram explicitamente o que caracteriza sociologicamente os pobres em relação aos demais membros da sociedade, nem explicaram, de forma completa, os modos de construção desta categoria e os laços que a vinculam à sociedade.

Georg Simmel (1907) retoma questões postas por Tocqueville um século antes e propõe uma análise explicitamente sociológica sobre a posição dos pobres na sociedade moderna (Paugam, 2005), definida com base na análise intersubjetiva da dádiva e a transição da caridade e da doação pública como obrigação moral cristã e a assistência pública, que só se reconhece plenamente no campo do direito. O conjunto de regulações de ordem moral implícitas à noção da "dádiva" (os significados da "esmola" na cultura cristã ocidental) explicita as relações complexas entre o indivíduo e o coletivo, retomando, por fim, a dimensão da cidadania dos pobres como condição do seu pertencimento e dos direitos. Nessa análise, ele destaca os paradoxos entre os princípios da indução moral da caridade (própria à ordem tradicional) e analisa as tensões que essa questão se reveste na teleologia do Estado moderno. A pobreza refere-se, portanto, a uma situação de reconhecimento da dívida social, permitindo associar direitos e deveres, quando a ideia da troca entre iguais não é mais possível no plano econômico.

\section{Três paradigmas sobre o pauperismo no século XIX: \\ Tocqueville, Marx \& Engels, e Simmel}

A contribuição desses quatro autores representa, em realidade, três paradigmas distintos sobre os significados da pobreza e das desigualdades sociais no capitalismo, que implicam formas de resolução política diversas. O retorno a essas contribuições elucida questões contemporâneas relativas às responsabilidades públicas num contexto de acumulação globalizada, em que o volume do 
"excedente" recoloca novos desafios, seja para a ação pública, seja para as implicações sobre a classe trabalhadora, e, enfim, em que as distâncias entre a pobreza e a riqueza ganham contornos mais complexos, devido à fluidez do capital numa economia globalizada.

Num esforço de síntese, essas contribuições podem ser esquematizadas em três paradigmas: o paradigma da igualdade - democracia liberal (Alexis de Tocqueville); o paradigma da exploração e das classes - da economia política (Karl Marx \& Friedrich Engels); e o paradigma da dádiva - do solidarismo e da cidadania (Georg Simmel).

O paradigma da igualdade, analisado por Tocqueville, refere-se ao reconhecimento dos cidadãos no âmbito do direito político, na democracia de caráter liberal, e encaminha a questão da assistência como de responsabilidade privada, e, portanto, da filantropia, restringindo a ação do Estado ao socorro da urgência, na garantia das condições mínimas da vida. O paradigma da exploração, desenvolvido por Marx \& Engels, entende a questão da pobreza como resultado da acumulação capitalista e da produção dos excedentes no mercado de trabalho e coloca o encaminhamento dessa contradição no campo da organização e luta dos trabalhadores, num diagnóstico de superação radical da estrutura, como condição de toda a sociedade. Dessa perspectiva, a assistência à pobreza é mitigadora, e se constitui apenas um alívio às condições de exploração, dificultando a verdadeira emancipação do trabalhador e da sociedade. A questão diz respeito, portanto, à redistribuição da riqueza. O terceiro paradigma, o paradigma da dádiva, apresentado por Simmel, contrapõe-se ao entendimento restrito da pobreza e dos pobres como "inúteis no mundo", "população extranumerária", ou "desqualificados sociais" e "indesejáveis", situando-os em termos de reconhecimento dos "direitos da cidadania" no contexto político republicano, e das formas institucionais que definem o vínculo desses indivíduos com a comunidade política. Ele supõe formas de representação negativas associadas aos vínculos sociais e entende que a saída do reconhecimento se dá no plano da cidadania. ${ }^{17}$

Esses três paradigmas, portanto, subsidiam debates clássicos, mas também atuais, sobre a natureza da proteção social, da distribuição e do reconhecimento. Polanyi (2000: 129-136) mostrou como os projetistas sociais ingleses, desde o século XVII, já apontavam para saídas distintas aos dilemas do pauperismo e do desemprego. John Bellers (1696), por exemplo, concebe uma alternativa ao desemprego e empobrecimento dos trabalhadores através de uma perspectiva solidarista de autoajuda. "Se o trabalho do pobre é a mina do rico", dizia Bellers, "por que eles não poderiam se manter explorando essas riquezas para o seu próprio benefício, mesmo deixando sobrar alguma coisa?" Bellers enxergava na troca direta de produtos entre os pobres uma via alternativa à bolsa de trabalho (Labor Exchange), que funcionava como uma agência de emprego. Para tanto, seria necessário organizá-los em cooperativas, o que, posteriormente, veio a se constituir no cerne do pensamento socialista em relação à pobreza e em alternativas para a economia solidária. A 
articulação entre suas notas de trabalho, a autoajuda e a cooperação é significativa na sua proposta. Seriam combinados o pagamento da sobrevivência com o pagamento conforme os resultados obtidos. O esquema nacional de Bellers para assistência ao desemprego, na verdade, seria dirigido por capitalistas e com lucro! Jeremy Bentham (1794) teve um plano de usar indigentes em grande escala para fazer funcionar sua indústria. Ele decidira aplicar o plano panóptico (pelo qual as prisões seriam projetadas de forma a tornar barata e efetiva sua supervisão) simplesmente à sua fábrica. Ou seja, ele transpõe o modelo de supervisão e sujeição das prisões para o da produção fabril, substituindo, nesse caso, os prisioneiros pelos pobres. Esse plano foi seguido por uma análise cuidadosa e classificatória dos desempregados. Na sua classificação a "mão de obra fora do lugar" era formada por aqueles que foram demitidos recentemente do emprego e distinguia-se de outros que não podiam encontrar emprego em função de sua "estagnação casual". A "estagnação periódica" dos trabalhadores sazonais era distinta da situação da "mão de obra superada", que se tornava "supérflua com a introdução da maquinaria". O último estrato identificado por Bentham consistia no grupo da "mão de obra dispersa", que adquiriu proeminência na guerra francesa à época vivida por Bentham. Polanyi (2000: 133) diz que o "plano de Bentham representava nada menos que o nivelamento do ciclo de negócios mediante a comercialização do desemprego em escala gigantesca. Robert Owen (1819), confiante na igualdade entre os homens, reeditou o plano de Bellers quase 120 anos depois.

Polanyi mostra que esses três homens entenderam que uma organização correta do trabalho dos desempregados deveria produzir um excedente: Bellers, o humanista, queria usar os excedentes basicamente na assistência aos sofredores; Owen, o socialista, queria devolvê-lo aos próprios desempregados; mas Bentham (o liberal utilitarista) desprezava a igualdade, ridicularizava os direitos humanos e se inclinava totalmente para o laissez-faire. O fato é que esses inúmeros projetos mostram que a questão social é polêmica e política, e seu encaminhamento envolve um conjunto de paradoxos que se reatualizam em função do arranjo político das forças sociais em cada sociedade.

\section{Os operadores normativos na modernidade:}

\section{a passagem do conflito à regulação}

As ciências sociais, desde as suas origens, ao assumirem a legitimação do processo modernista de transformação da sociedade, promoveram também, no plano teórico-crítico, a dissolução do seu próprio objeto, na crítica ao utilitarismo e, paradoxalmente, "no plano prático, acabou por substituir-se à sociedade, à socialidade e à historicidade, pela regulação tecnocrática da realidade social" (Freitag, 1987: 34).

Do ponto de vista da sociologia da integração social, Durkheim deslocou a referência utilitarista do indivíduo para a sociedade como um todo. Se 
a sociedade capitalista-industrial ou estatal-nacional do século XIX e começo do século XX, nascida da autonomização econômica da sociedade civil, traz, em si, a contradição de classes - que mina a legitimidade da representação formal - , os arranjos das políticas reformistas implantadas desde o século XIX, sob pressão do movimento trabalhador, vão desmentir o caráter natural dessa economia de mercado e do laissez-faire. A moderna sociedade industrial adquire progressivamente legitimidade como "sociedade do crescimento", ocultando e naturalizando o modo conflituoso dos interesses das classes.

Os direitos sociais e as políticas sociais, ao mediarem as contradições entre a economia e a política; entre o trabalho e o capital; entre a ciência e a técnica; entre a participação política e a vida familiar e cultural, constituem mediações que substituem as antigas estruturas de regulação de caráter societário e a sua legitimação a partir da autoridade tradicional. "Elas asseguram a superação da tradição, tanto no plano ideológico como no plano prático, ou seja, como forma e sistema operatório efetivos da regulação das relações sociais e como referência da legitimação" (Freitag, 1987: 61).

As normas do "bem-estar", da "satisfação das necessidades", da "autonomia do indivíduo", "da igualdade perante a lei”, da "liberdade de participação política", da "soberania da consciência reflexiva", tomadas no campo cognitivo como fundamentos da pretensa objetividade, não constituem apenas "mitos" da sociedade do crescimento, mas integram as práticas sociais como "operadores" normativos e institucionais; como expressão de "finalidades" que asseguram sua legitimação e conferem sentido a todo o projeto da modernidade. Assim, a modernidade enunciou uma versão abstrata, formal e apurada, suscetível de ser interiorizada em cada indivíduo sob a forma de identidade pessoal e de valor ético-normativo. Tal estrutura não suprimia a unidade a priori da sociedade, mas projetava, no futuro, a ideia utópica de uma sociedade inteiramente unida pela razão e tornada transparente pela consciência de si mesma (Freitag, 1987: 62). Desta forma a modernidade criou mecanismos de regulação social suscetíveis de conduzir, de maneira prática, uma ordem mínima de convívio social, ambígua porque integrava e legitimava a ordem, ocultando as contradições dessa mesma ordem.

Tal ordem se define, na primeira modernidade, para usar a expressão de Beck (2001: 13), no marco do Estado-nação, na noção de pleno emprego, quando as políticas sociais (de bem-estar social) e a organização cotidiana das biografias têm por vetor a plena ocupação e a mobilidade social. Em segundo lugar, as sociedades se constituem através de identidades coletivas, mais ou menos homogêneas, com ênfase na identidade de classes, grupos ou etnias. Ademais, elas se definem pelo mito do progresso, supondo que os problemas gerados pelo desenvolvimento industrial possam ser superados pelo avanço da técnica, da mobilidade ascendente e da integração dos trabalhadores, acompanhando a perspectiva evolutiva do mito do progresso. 


\section{O "SOCIAL", UMA NOÇÃo TEÓRICO-METODOLÓGICA AMBIVALENTE}

A noção do "social" é, portanto, ambivalente e acompanha as dificuldades de explicitação das relações paradoxais entre as representações burguesas e liberais dominantes e as formas de estruturação desigual do trabalho nas sociedades capitalistas. O social aparece ao mesmo tempo como um campo de regulações não-mercantis, mas diz respeito também à "posição" e condição de indivíduos e trabalhadores empobrecidos a partir da forma de sua inserção no mercado de trabalho capitalista.

O "social" integrava a dimensão da ordem social ${ }^{18}$ ameaçada pela pressão dos homens livres que não encontravam um lugar na organização do trabalho. Essa "ameaça à ordem" dos trabalhadores livres ocorre, sobretudo, no território das cidades em formação. Adam Smith em A riqueza das nações (1776) oferece um campo conceitual dessa dimensão, orientando a representação filantrópica, estética e ao mesmo tempo repressiva da pobreza, no processo de urbanização das sociedades industriais. A interpretação de Smith sobre a "massa de homens sem propriedade vista como o(s) inimigo(s) da ordem pública", expressa uma representação até hoje prevalecente, que articula o encaminhamento da pobreza (especialmente urbana) a uma visão repressiva ou à ideia de uma ordem social ${ }^{19}$ exclusivamente regulada pelos proprietários.

Essas dimensões histórico-sociais têm implicações teórico-metodológicas (como analisa Giddens, 1994). A primeira é a confusão entre sociedade e sistemas sociais. Essa perspectiva reifica a questão social, traduzindo-a nas formas institucionais regulatórias do Estado-nação, e do ponto de vista metodológico se expressa num nacionalismo metodológico nas ciências sociais, para usar a expressão de Beck (2001). Ou seja, na delimitação da sociedade restrita aos limites do Estado-nação. Dessa forma, a questão social é "retraduzida e localizada" como um sistema de políticas sociais e públicas do ponto de vista do sistema técnico gerencial, confundindo a sociedade e as relações políticas com os modos regulatórios e instrumentais desta própria sociedade.

Uma segunda dimensão problemática do "social", associada à perspectiva sistêmica, refere-se à dimensão da defesa da "ordem" e às modalidades de controles de uma sociedade. Dessa perspectiva, o papel regulatório das políticas sociais, como modos de "integração e adaptação social", volta-se para tornar a sociedade coesa, em face dos diferentes e contraditórios interesses sociais. ${ }^{20}$ Em contraposição a essa visão encontra-se um paradigma que reconhece a natureza conflituosa e paradoxal, inerente ao processo de redistribuição entre proprietários e não proprietários, entre trabalhadores e capitalistas, na reprodução da ordem social.

Neste sentido, o encaminhamento da questão social representa ao mesmo tempo melhorias para as condições de reprodução social das famílias trabalhadoras, na ordem capitalista, mas são limitadas, tanto por controles sociais que 
regulam as condições do trabalho, no sentido de rebaixamento do valor trabalho, como gerenciam a aplicação dos benefícios sociais assistências e os direitos sociais mais universais. A associação dessas duas dimensões, a do controle da ordem social e a dos direitos do trabalhador, expressam um campo de controvérsias e luta por hegemonia dos liberais quanto ao destino da riqueza social.

Por fim, a "invenção do social" na modernidade, ao integrar o projeto "iluminista" do progresso social, contrapondo-se parcialmente à radicalização do homo œconomicus, também ultrapassa as estruturas e formas institucionais do Estado, para se efetivar no plano das práticas sociais e das formas concretas como os sujeitos encaminham no cotidiano as condições de sua resistência e as alternativas de sua integração, orientadas segundo valores que instituem a normatividade das suas próprias sociabilidades. Assim, os controles estruturados e os mecanismos sociais são insuficientes para entender o que "faz sociedade", ou para saber como se constrói a solidariedade.

Esta resulta da forma efetiva como os atores sociais - através das modalidades de intervenção, de seus interesses, de suas representações e de suas práticas e redes sociais - se organizam e dão sentido às formas institucionais. E essas relações não são lineares, mas paradoxais. A representação coletiva unificadora (Durkheim) tem uma idealização do bem-estar material, nas democracias liberais, de promoção do Eu - individual (Laval, 2002: 33). E esse é um paradoxo das sociedades capitalistas.

Essas diversas dimensões do social podem deslocar o princípio da defesa da vida social, radicalizando o princípio utilitarista de organização da vida social e institucional, como norma legítima da ordem social, subordinando o social à técnica de gerenciamento dos benefícios. Hannah Arendt (1983) chama a atenção para a transmutação do "social" naturalizado em "técnica", em detrimento da política. Para ela, quando o desenvolvimento tecnológico passa a se constituir no elemento central de superação da escassez, a gestão das políticas e o seu modo de operação assumem a prioridade de avaliação da política social, traduzindo e transformando "a questão social" em problema de gestão de metas, de gestão do gasto social, priorizando a dimensão estratégica do Estado, no contexto contemporâneo. Essa versão instrumental-gerencial do "social", não concebe "a sociedade", as tensões políticas do seu ordenamento, mas traduz o "social" como técnica, na forma inteiramente quantificável dos beneficiários, subordinando a dimensão da justiça e do bem-estar à eficácia da alocação de benefícios e à gestão estratégica do volume da distribuição nos limites mínimos aceitos pela sociedade.

Para Arendt, a "absolutização da questão social" implicou estreitamento da noção de bem comum restrita às condições materiais de bem-estar das populações. Essa redução da questão social à reprodução material tornou o "social" um meio a serviço da acumulação e da abundância. Embora Arendt não se coloque contra o encaminhamento da "questão social", ela critica os defensores 
do sacrifício da esfera pública, necessariamente política, para tornar eficaz o problema da escassez e da pobreza. Para ela, a grandeza humana não se reduz à maximização do que se pode alcançar, mas se realiza na convivência humana, onde se expressa o "quem" ou o sujeito social e não apenas as "funções" sociais, como analisava Simmel a respeito da teleologia do Estado moderno em relação aos pobres. Esse espaço é conflituoso e se constitui na pluralidade dos seres individuais, acrescento. O sacrifício dessa dimensão em nome do crescimento econômico não gera a solução do problema social, uma vez que as sociedades da abundância, para Arendt, não geram cidadãos, mas produzem, fundamentalmente, consumidores. Além do mais, a absolutização da questão social pela técnica pode dar lugar a violências sem limites..$^{21}$ Essa crítica de Hannah Arendt refere-se especialmente aos regimes autoritários, a exemplo da experiência de implantação do seguro social bismarckiano encaminhado por um Estado autoritário e pode refletir, a meu ver, a natureza da implantação de leis sociais no contexto autoritário da modernização brasileira.

\section{CONCLUSÃO}

Este artigo analisou a constituição da questão social no marco das sociedades modernas urbano-industriais como uma grande invenção social da modernidade, na qual a ambição sociológica esteve diretamente imbricada. Essa reflexividade entre a questão social e a construção sociológica, entre esta e a estruturação das instituições modernas das sociedades urbano-industriais, forneceu as bases teórico-metodológicas que permitem identificar dilemas e singularidades no encaminhamento da questão social contemporânea, marcado pelo desemprego de massa e de longa duração e pela reforma liberal do Estado social.

Os campos institucionais, próprios do estado de bem-estar social, se estruturaram na forma de uma "socialização da economia" (Offe, 1984; Santos, 1999), por meio da qual se reconhecia que o capitalismo não era apenas constituído por fatores de produção e pelo mercado, mas por sujeitos sociais com necessidades básicas, que se constituem em cidadãos de direitos. Esse processo se traduzia no marco normativo e institucional dos Estados nacionais, na regulação da economia e na mediação do conflito entre acumulação e emancipação social, que expressa uma "politização do Estado". Como anteriormente indicado, Esping-Andersen (1990) se refere a esses processos como "desmercantilização" do trabalho.

As mudanças dos anos 1980 e 1990, de reestruturação produtiva e reforma do Estado social, operaram uma ruptura nos pilares deste modelo, através de uma dessocialização da economia por mudanças nos regimes de proteção social, aumento crescente do desemprego e da precarização, e, ao mesmo tempo, de uma "despolitização do Estado" na mediação do conflito redistributivo, constrangido 
pela autorregulação do mercado. ${ }^{22}$ Estes processos produziram uma ruptura do modelo clássico que articula proteção e trabalho, proteção e solidariedade nacional (Ivo, 2005). Isto quer dizer que a proteção passa a ser encaminhada, fora do universo do trabalho e que a regulação do conflito redistributivo opera sob modalidades que não comprometem a liberdade dos capitais.

Diante dos efeitos adversos e da gravidade dos ajustes (econômicos e institucionais) dos anos 2000, no entanto, a sociedade reconheceu a necessidade de refundação do Estado social, de modo a minimizar os efeitos adversos dos ajustes institucionais. Estes priorizaram as políticas monetárias de transferência de renda mínima aos segmentos extremamente pobres e um modelo estratégico de combate à pobreza por políticas sociais focalizadas, em áreas que não comprometam o núcleo central dos ajustes e das políticas securitárias, nem a liberação dos mercados.

No entanto, a concepção que orienta esse processo responde por tradições diversas. Em relação às propostas de renda mínima, identificam-se, na Europa, no contexto contemporâneo, três paradigmas: o do contrato, o do direito e o da dádiva (ver Chanial, 2004). O paradigma do contrato é defendido por Pierre Rosanvallon (1995); para este, nenhuma renda pode estar desconectada de uma atividade de trabalho. O paradigma do direito é defendido especialmente por J-M. Ferry $(1995,1996)$, que justifica o direito à renda, integrando-a às regras constitucionais dos direitos democráticos. O terceiro paradigma, antiutilitarista, o da dádiva, questiona os anteriores (o do contrato e o do direito), rearticulando os princípios da dádiva à incondicionalidade e à condição da cidadania (Caillé, 2002).

A crítica de Rosanvallon (1995: 122-125) à renda incondicional é que sua implantação gera um sistema de proteção social puramente indenizatório, na forma de um "Estado-providência-passivo", como "um direito sem contrapartida, um direito sem dever". A sua crítica funda-se no imaginário contratualista que estabelece uma ideia de equivalência, ou seja, a de que ninguém pode receber uma ajuda sem uma contrapartida para a coletividade. Portanto, a integração via política social pressupõe a utilidade social ou o compromisso com a coletividade. Segundo este paradigma do contrato, na hipótese em que a reciprocidade entre direitos e deveres é rompida a cidadania fica ameaçada, já que a relação entre direitos e deveres consistiria a base de todo laço cívico, conforme Rosanvallon (1995). Mesmo que os direitos inerentes à cidadania justifiquem o direito à renda como um direito à vida, esse direito, para ele, não pode estar separado de obrigações positivas desses cidadãos. Todo direito à renda supõe o direito ao trabalho, ou, utilizando os termos de Rosanvallon, supõe um dever de inserção ou de utilidade social. ${ }^{23}$

O paradigma da dádiva rompe de forma radical com o imaginário contratualista e reafirma o princípio da incondicionalidade de acesso aos direitos fundamentado em dois princípios morais: o do valor das pessoas e a cidadania 
democrática. A atribuição de uma renda desconectada da prestação de trabalho consiste em reconhecer, primeiramente, dignidade igual para todos, independente de sua situação profissional, possibilitando a cada um escapar da miséria e dos estigmas sociais, como também da servidão e da humilhação próprias à tutela da assistência.

Por outro lado, considera que o pacto democrático tem um valor intrínseco, como analisa Chanial, já sugere que ele não seja cogitado sob o princípio corporativo do contrato, e que a condição da cidadania não esteja limitada ao cálculo dos direitos e das obrigações, como indicava Simmel (1998). Uma pessoa é legitima, e se constitui em sujeito de direitos porque a fazemos cidadã. Somente a partir desta condição é que se pode exigir dela qualquer civismo, e não o contrário. Nesse sentido, a cidadania distingue-se do registro do contrato das prestações, estruturado sobre o princípio "é dando que se recebe". O direito à proteção é incondicionalmente reconhecido como princípio universal da cidadania, de forma a que o indivíduo autônomo possa, de retorno, agir como cidadão. Tal é o sentido do desafio da renda incondicional da cidadania.

O esforço da busca de alternativas contemporâneas não é tarefa simples, por várias razões. Primeiramente, porque estamos falando de uma realidade submetida a mudanças radicais, na qual algumas dessas teses ainda não foram suficientemente submetidas à crítica. Em segundo lugar porque, no campo dessas mudanças, patinamos sobre novos princípios e categorias de análise que aproximam, muitas vezes, tradições políticas contraditórias, como liberalismo e socialismo, como analisa Lo Vuolo (2004), ao falar sobre a renda mínima de cidadania. Essa zona cinzenta ${ }^{24}$ gera polissemia conceitual e pouca clareza quanto à direção da política. Essa ambiguidade participa, em realidade, de movimentos de construção de hegemonia e contra-hegemonia do processo de transição em curso, no qual os princípios que organizaram a formação do estado de bem-estar social estão reformulados, em favor do mercado.

Artigo recebido para publicação em março de 2011.

Anete B.L.Ivo é socióloga, doutora em Sociologia pela Universidade Federal de Pernambuco (UFPE), professora do Programa de PósGraduação em Ciências Sociais e pesquisadora do Centro de Recursos Humanos da Universidade Federal da Bahia (UFBA). Foi titular da Cátedra Simon Bolívar (Université de Paris III, 2000) e professora convidada da Université de Paris XII, 2006. É autora de artigos e livros de sociologia, publicados no Brasil e no exterior, nas temáticas: modernidade e questão social; pobreza, desigualdades e políticas sociais; espaço público e ação coletiva, destacando-se os livros Metamorfoses da questão democrática (2001) e Viver por um fio (2008). 


\section{NOTAS}

1 A obra de Karl Polanyi, A grande transformação (1944) é a grande inspiração dessa "invenção social", do ponto de vista heurístico. O título, no entanto, inspira-se no livro com título homônimo L'invention du social, de Jacques Donzelot (1994), que analisa a emergência do Estado social, na França, especialmente da perspectiva das instituições de direitos políticos. O "social" aqui diz respeito às mediações criadas pela sociedade e o Estado para mitigar os riscos resultantes da constituição do mercado de trabalho capitalista e não se confunde com a noção de societal, que diz respeito ao atributo relacional da sociedade humana e seus membros, à vida em grupo etc.

2 A noção de modernidade, na sua acepção mais frequente se refere ao que é contemporâneo, ao tempo presente, submetido a uma inquietude constante (Martucceli, 1999: 9). Para Giddens (1994) ela designa um modo de vida e uma organização social que apareceu na Europa no século XVIII e teve influência planetária. A noção contém um valor moral de mudança contra a tradição por meio da razão (Touraine, 1992), que envolveu progresso técnico e novo padrão de consumo e modo de vida, resultante da nova ordem urbano-industrial. Neste artigo, a noção faz apelo a um tempo histórico de instauração da ordem burguesa urbano-industrial, e aos desafios da ruptura das modalidades de proteção tradicionais e criação de instituições modernas, do Estado e dos direitos sociais. Ao mesmo tempo considera a prevalência da ciência (sociologia) como ordenadora desta nova ordem.

3 Karl Marx mostra que por trás da compra e venda da força de trabalho e do desenvovolvimento técnico se escondem processos de dominação econômica, social e política dos trabalhadores pelo capital.

4 Antigo Regime (Ancien Régime) implica a transição do feudalismo para o capitalismo, a passagem da sociedade estamental para a ordem burguesa. Esta expressão foi usada por Tocqueville no ensaio L'Ancien Régime et la révolution (O Antigo Regime e a revolução) de 1856, publicado no Brasil pela Martins Fontes em 2009. 
5 Essa é a perspectiva inerente à visão liberal, que atribui aos pobres a responsabilidade sobre a sua própria condição e destino. Alexis de Tocqueville, no texto Memoire sur la paupérisme (1835) faz importante crítica à "caridade pública", a respeito das intervenções do Estado em relação ao "socorro" aos pobres.

6 A passagem de uma análise histórica singular como um paradigma relativo a mediação do Estado social em outros países deve ser assumido com cautela e considerar a singularidade histórica de formação social de cada sociedade, sua cultura política e as formas concretas e ambivalentes de estruturação dos regimes de proteção social. Neste texto não recupero as relevantes e importantes contribuições da literatura brasileira sobre o enigma da questão social, no Brasil, dado os limites deste artigo. Um esforço inicial, e ainda provisório, foi feito da perspectiva da sociologia no meu livro Viver por um fio (Ivo, 2008).

7 Para Habermas a normatividade moral articulava-se com a questão social e política de institucionalização da formas de vida, distinta da concepção sistêmica que atende às exigências funcionais e operacionais do mundo da vida. Este é compreendido pelo autor como as formas efetivas de reprodução cultural, societal e pessoal através de normas consensualmente aceitas.

8 Ver também Schwartzman (2004) sobre a emergência da pobreza como questão sociológica, no contexto de formação da sociedade burguesa, especialmente ao final do século XIX.

9 Émile Durkheim deu estatuto teórico a essa noção no livro A divisão do trabalho social (1989).

10 Ver Jamur (1999), que analisa a construção dos processos institucionais de solidariedade.

11 Segundo Giddens (1994: 45), a reflexividade, na modernidade, significa o exame e a revisão constante das práticas sociais à luz de novas informações relativas a essas próprias práticas, reiterando constitutivamente o caráter dessas e sua reflexão.

12 Essa racionalidade retorna e intervém sobre as práticas e representações sociais. 
13 Essa reflexividade participa da reprodução do sistema, de maneira que pensamento e ação se refletem constantemente um sobre a outra, na modernidade.

14 Essa dimensão é fundamental, pois a "norma metodológica" que se confronta com a crítica à normatividade da sociologia desconhece o fato de ela mesma se constituir numa "norma social" própria à dimensão cultural da ciência.

$15 \mathrm{O}$ utilitarismo constitui-se numa doutrina que se expandiu nos séculos XVIII e XIX. O termo foi inventado por Bentham e reinventado por Stuart Mills. Além deles, figuram como autores principais dessa doutrina Adam Smith, Ricardo, James Mills, Alfred Marshall, Henry Sidgwick e Herbert Spencer. O que os articula nesta "doutrina" é o papel do interesse na ordem e na mudança social. O fato de a Inglaterra, na época moderna, não ter conhecido o regime da monarquia absoluta e centralizada e as diversas mudanças sociais e econômicas que aí se processaram explicam, sem dúvida, em parte, a centralidade do pensamento utilitarista como um fenômeno inglês (Boudon \& Bourricaud, 1982).

16 Marcel Mauss dispõe os primeiros elementos de uma sociologia explícita do simbólico. Para ele, a base de uma sociedade é a capacidade de desenvolver trocas. Essas podem ser materiais ou simbólicas, sempre se considerando a distribuição e a circulação desse elemento. Max Weber busca uma interpretação da vida social (deutend verstehen) de forma a desvendar o sentido que os atores atribuem às suas próprias posições para além da sua simples descrição. Ele critica o economicismo sem renunciar à visão atomizada e individualizada do indivíduo egoísta. Reis (1989) considera que "O homo sociologicus weberiano é, na verdade, análogo ao homo œconomicus. Ele é um dos recortes analíticos possíveis do indivíduo atomizado, gerado pelo mesmo movimento de racionalização que dá origem à ciência moderna, ao capitalismo, à tipificação do indivíduo racional etc." Karl Marx desenvolve a noção de fetichismo da mercadoria, pela qual a mercadoria e o capital aparecem como "coisas", e não como relações sociais e trabalho materializado. Essa relação, no entanto, não é falsa. Ela existe, mas oculta e falsifica a relação de exploração do trabalho aí constituído. 
17 Estaria aí uma tese que fundamentaria as teorias do reconhecimento contemporâneas?

18 Sobre essa perspectiva da ordem, ver Hélène Thomas (1997). Para ela, tanto as proteções civis como as assistenciais integravam essa dimensão da sociedade da ordem.

19 Kowarick (1987) mostrou as relações entre cidade e questão social, no Brasil. Ele articulou a dimensão da ordem e as formas repressoras no espaço urbano brasileiro. Ver, também, Valladares (1991) e Bresciani (2002).

20 Durkheim indagava o que faz e torna uma sociedade coesa. Algumas interpretações sociológicas, como a de Talcott Parsons, priorizam a dimensão dos controles na análise da sociedade.

21 Essas críticas de Arendt resultam de um contexto analítico das reformas sociais realizadas em meio ao totalitarismo na Alemanha de Hitler e na Rússia de Stalin e, por outro lado, à sua perspectiva de construção de um espaço público e cívico da sociedade americana, onde ela viveu até a sua morte (1975).

22 Especialmente no que se refere às relações entre capital e trabalho. Em relação às ações de assistência aos mais pobres, ao contrário, foi mais forte.

23 Este registro da equivalência do contrato, segundo Chanial, é também o de John Rawls, que discutiu a justiça como equidade. $\mathrm{O}$ imposto negativo, que complementa uma renda, supõe uma prestação de trabalho.

24 Refiro-me ao caráter nebuloso e ainda pouco claro, porque subordinado a contextos conceituais e valorativos distintos.

\section{REFERÊNCIAS BIBLIOGRÁFICAS}

Arendt, Hannah. A condição humana. Rio de Janeiro: Forense, 1983.

Aron, Raymond. Les désillusions du progrès: essai sur la dialectique de la modernité. Paris: Calmann-Lévy, 1969.

Beck, Ulrich. Políticas alternativas a la sociedad del trabajo. In: _____; Le Grand, Julian; Glennerster, Howard; EspingAndersen, Gosta \& Paugam, Serge. Presente y futuro del esta- 
do de bienestar: el debate europeo. Buenos Aires: Miño y Dávila Editores, 2001, p. 13-29.

Boudon, Raymond \& Bourricaud, François. Dictionnaire critique de la sociologie. Paris: PUF/Quadrige, 1982.

Bresciani, Maria Stela. Cidade e história. In: Oliveira, Lucia Lippi (org.). Cidade: história e desafios. Rio de Janeiro: Ed. FGV, 2002, p. 16-35.

Caillé, Alain. A antropologia do dom: o terceiro paradigma. Petrópolis: Vozes, 2002.

Castel, Robert. Les métamorphoses de la question sociale: une chronique du salariat. Paris: Fayard, 1995.

Chanial, Phillipe. Além do domínio do interesse? Dádiva, proteção social e renda da cidadania. Caderno CRH: Revista do Centro de Recursos Humanos, 2004, 17/40, p. 17-32.

Esping-Andersen, Gosta. The three worlds of welfare capitalism. Cambridge: Cambridge University Press, 1990.

Donzelot, Jacques. L'invention du social: essai sur le declin des passions politiques. Paris: Seuil, [1984] 1994.

Dürkheim, Émile. A divisão do trabalho social. Lisboa: Presença, [1893] 1989.

Ewald, François. L'État providence. Paris: Grasset,1986.

Ferry, Jean-Marc. L'allocation universelle. Paris: CERF, 1995.

Revenu de citoyenneté, droit au travail, intégration sociale. La Revue du M.A.U.S.S., 1996, 7, p. 115-134

Freitag, Michel. La crise des sciences sociales entre epistemologie et ideologie: la place de la question de la normativité dans le développement de la connaisssance de la société. Bulletin du M.A.U.S.S., 1987, 22, p. 13-65.

Giddens, Anthony. Les conséquences de la modernité. Paris: L'Harmattan, 1994.

A new rule of sociological method. Londres: Hutchinson, 1974.

Guimarães, Jussemar W. A Revolução Francesa e a invenção social da pobreza. Biblos: Revista do Instituto de Ciências Humanas e da Informação, 2009, 23/1, p. 9-24.

Habermas, Jürgen. Crítica de la razón funcionalista. In: Teoría de la acción comunicativa. Madri: Taurus, 1987 (vol. 2). 
Ivo, Anete B. L. The redefinition of the social issue and the rethoric on poverty during the $90 \mathrm{~s}$. In: Cimadamore, Alberto; Hartley, Dean \& Siqueira, Jorge (orgs.). The poverty of the state: reconsidering the role of the state in the struggle against global poverty. Buenos Aires: CLACSO/CROP, 2005, p. 65-90. - Viver por um fio: pobreza e política social. São Paulo: Annablume, 2008.

Jamur, Marilena. Solidariedade(s). O Social em Questão, 1999, $4 / 4$, p. 25-60.

Kowarick, Lúcio. Trabalho e vadiagem: a origem do trabalho livre no Brasil. São Paulo: Brasiliense, 1987.

Laval, Christian. L'ambition sociologique: Saint-Simon, Comte, Toqueville, Marx, Durkheim, Weber. Paris: La Decouverte, 2002 (Recherches).

Lévy, Catherine. Viure au minimum: enquête dans l'Europe de la précarité. Paris: La Dispute, 2003.

Lo Vuolo, Ruben. A modo de presentación: los conceptos del ingreso ciudadano. In: et al. Contra la exclusión: la propuesta del ingreso ciudadano. Buenos Aires: Miño y Dávila/ CIEPP, 2004, p. 17-51.

Martucceli, Danilo. Sociologies de la modernité: l'itinéraire du XXe. siècle. Paris: Gallimard, 1999.

Marx, Karl. El Capital. Libro I. México: Siglo XXI, [1867] 1975. Disponível em: <www.ucm.es> Acesso em 23 set. 2007.

Offe, Claus. Problemas estruturais do Estado capitalista. Rio de Janeiro: Tempo Brasileiro, 1984.

Oliveira, Francisco de. A economia brasileira: crítica à razão dualista. 2. ed. São Paulo: Brasiliense, [1972] 1976, p. 7-78.

Paugam, Serge. Les formes élémentaires de la pauvrété. Paris: Presses Universitaires de France, 2005.

Perrot, Jean-Claude. Une histoire intellectuelle de l'économie politique XVII-XVIII siècles. Paris: Editions EHESS, 1992.

Polanyi, Karl. A grande transformação: as origens da nossa época. Rio de Janeiro: Elsevier, [1944] 2000.

Reis, Elisa. Reflexões sobre o "Homo Sociologicus". Revista Brasileira de Ciências Sociais, 1989, 4/11, p. 23-33. Disponível em <http://www.anpocs.org.br/portal/publicacoes/ rbcs_00_11/rbcs11_02.htm>. Acesso em 15 maio 2012. 
Rosanvallon, Pierre. La crise de l'État providence. Paris: Seuil, 1981.

. La nouvelle question sociale: répenser l'État-providence. Paris: Seuil, 1995.

Santos, Boaventura de S. Reinventar a democracia: entre o pré-contratualismo e o pós-contratualismo. In: Oliveira, Francisco de \& Paoli, Maria Célia (orgs.). Os sentidos da democracia: políticas do discurso e hegemonia global. Petrópolis: Vozes, 1999, p. 83-129.

Simmel, Georg. Les pauures. Paris: Presses Universitaires de France, [1907] 1998.

Schnapper, Dominique. Préface. In: Paugam, Serge. La disqualification sociale. Paris: Presses Universitaires de France, 1991, p. iv-xi.

Schwartzman, Simon. Pobreza, exclusão social e modernidade: uma introdução ao mundo contemporâneo. São Paulo: Augurium, 2004.

Thomas, Hélène. La production des exclusion: politiques sociales et processus de désocialisation socio-politique. Paris: Presses Universitaires de France, 1997.

Tocqueville, Alexis de. Mémoire sur le paupérisme. In:

Euvres complètes - Mélanges: Tome XVI, [1835] 1958, p. 117139.

O Antigo Regime e a revolução. São Paulo: Martins Fontes, [1856] 2009.

Touraine, Alain. Critique de la modernité. Paris: Fayard, 1992.

Valladares, Lícia do P. Cem anos repensando a pobreza (urbana) no Brasil. In: Boschi, Renato (org.). Corporativismo e desigualdade: a construção do espaço público no Brasil. Rio de Janeiro: Rio Fundo, 1991, p. 81-112.

Vovelle, Michel. Piété baroque et déchristianisation en Provence au XVIIIe siècle. Paris: Seuil, 1978. 
Palavras-chave:

Teoria social; Normatividade das ciências sociais;

Questão social; Utilitarismo; Pobreza.

Keywords:

Social theory; Normativity of the social sciences;

Social issue; Utilitarism; Poverty.

\section{Resumo:}

O artigo discute as relações entre a sociologia e a questão social, explorando a dimensão cultural da ciência na organização da sociedade, na modernidade, na qual a sociologia é produto e produtora desta ordem. $\mathrm{O}$ artigo se estrutura em três partes: a primeira analisa a invenção da propriedade social do Estado na proteção social. A segunda contrapõe o homo sociologicus ao homo œconomicus, analisando a pauperização, como o fenômeno sobre o qual se constrói a crítica ao utilitarismo. A terceira apresenta três matrizes paradigmáticas sobre a pobreza na sociedade da abundância (Tocqueville, Marx \& Engels, e Simmel). Na conclusão apresenta três paradigmas (o do contrato, do direito e da dádiva), que tentam refundar a proteção social de uma perspectiva do direito incondicional de todos os cidadãos a uma renda mínima universal.

\section{Abstract:}

The article discusses the relations between sociology and the social issues, exploring the cultural dimension of science in the organization of society in the modern age, in which sociology is at once the resulting effect and the producer of this order. The text is divided into three parts: the first examines the invention of the social property and the role of social protection by the State. The second contrasts the homo sociologicus and the homo oconomicus. The impoverishment appears as the empirical phenomenon against which the critique of utilitarianism is mounted. The third presents three theses on poverty in capitalist society (Tocqueville, Marx \& Engels, and Simmel). To conclude this article presents three contemporary paradigms: that of the contract; the second based on the law, and the third based on the theory of gift exchange trying to redefine social protection from the perspective of a unconditional right to a universal basic income to all citizens. 